\title{
The Effect of Community Empowerment Program for Fisherman Community to Enhance the Market Penetration a Case Studies in Tuban Indonesia
}

\author{
Nova Retnowati \\ Management Department-Bhayangkara University, \\ A. Yani 114, Surabaya, Indonesia \\ Dr. Muslichah Erma Widiana \\ Management Department-Bhayangkara University, \\ A. Yani 114, Surabaya, Indonesia
}

Soeharjoeprib

Natural Science Department-Sepuluh Nopember Institute of Technology, Sukolilo, Surabaya, Indonesia

\begin{abstract}
This study is an action research study in the form of community empowerment program. The study aim to help the fisherman community to growth in two aspect one is the production line and second is enhance the market penetration. The market penetration is required to increase the profit and minimalist the loss due to unsold product. The program is done in Tuban a district in East Java located in Indonesia. The program is done in many aspect from production standard procedures until the marketing management and branding process. The result of this study is shown that the increase of quality of production and also minimalist the time required, furthermore the result also shown the increase of market penetration through branding technique.
\end{abstract}

Keywords: Community Empowerment Program, Market Penetration, branding.

\section{INTRODUCTION}

Indonesia is a maritime country with the world's largest sea area and the second longest coastline in the world after Canada. Natural resources from marine products are very abundant, especially shrimp and fish. Fishery products are food products that have very high nutritional value. Based on statistics from the Ministry of Maritime Affairs and Fisheries, the level of national fish consumption in the period 2007-2012 experienced an upward trend every year.

One type of fish that is Indonesia's main export commodity is tuna. Tuna fish processing in Indonesia is generally done by fileting method to obtain the meat. There are many industries that do tuna processing in Indonesia, but most of them are done by SMEs. Small and medium businesses become one of the breakthroughs to increase economic growth in the midst of society to achieve adequate living prosperity. Small and medium businesses become the support of the Indonesian economy, because it helps the growth of the community's economy. Community independence such as the SME business people are expected to be able to reduce unemployment if they see the fact that employment is increasingly limited with the number of workers who have not been absorbed continues to grow. 
The existence of SME business players contributes significantly to economic development. In this case the business they built absorbed the workforce in their respective regions. This greatly helps the government in an effort to reduce unemployment and poverty alleviation. It is expected that the development of SME business from time to time will experience a steady increase. However, in the journey to develop more advanced, SME business people cannot be separated from obstacles. So that the intervention of the government and the private sector is needed to encourage the development that is expected together. The side product produced from tuna processing in this place is tuna skin.

There is a lot of tuna skin waste produced in Tuban and the surrounding areas previously cannot be absorbed because it did not have a profitable economic value because it was not processed. Tuna fish skin has the potential to be able to become a variety of other products. Tuna fish skin can be processed into gelatin, food products and can also be cooked.

Based on this, dedication activities focus on processing tuna skin to become tuna skin cracker products starting from the stage of composition, drafting, to the pattern of the production process. After obtaining the right concepts and production process patterns, then proceed with conducting a business feasibility analysis of the use of tuna fish skin as raw material in making tuna skin crackers, whether feasible and fulfilling the technical and financial aspects to be implemented.

Processed fish skin crackers are also in demand in the market. The increasing number of lovers of fish skin crackers, will automatically add to the cracker industry that has sprung up. This cracker business is very suitable to run in the area around the beach because in obtaining raw materials is very easy. Fish cracker business can also be said to be one of the most profitable businesses and the manufacturing process is not difficult. This fish skin cracker business opportunity is still very wide open, by running fish skin cracker business activities can bring profits. To carry out the business activities of fish skin crackers is very easy and also does not require large capital.

Relationship marketing is one of the company's strategy by maintaining good relationship with customers in the long run. This strategy focuses more on how to maintain existing customers, so as not to move to competing products (Zeithaml et al., 2006). Relationship marketing is an effort to attract, maintain, and improve long-term relationships with customers. Therefore, it is important for the company to be more concerned with customers, because one of the key factors of the company to survive in the current market is to maintain and maintain long-term relationships with customers (Perrien and Richard, 1995). Relationship marketing is a philosophy in doing a strategic-oriented business, which focuses on maintaining and improving the quality of customer relationships today instead of focusing on efforts to acquire new customers (Palmatier et al., 2006). This philosophy assumes that many customers and business customers prefer to have a sustainable relationship with one company instead of having to move to another company, as long as the company is able to deliver value and meet the expectations of its customers, therefore keeping customers current will make the company cost much less than by trying to attract new customers using conventional marketing communications such as advertising (Sui and Baloglu, 2003). For that reason the company must be able to provide a benefit or benefit to the customer from the relationship built to the customer (Rauyruen and Miller, 2007). Successful marketers will work with using effective strategies to retain customers by continuing to provide long-term satisfaction (Hennig Thurau and Klee, 1997). Giving benefits from a relationship or relational benefit can actually benefit both parties, both customers and companies (Ruiz Molina et al, 2009). 
The advantages in question is when companies implement relationship marketing strategy, the company will be able to know in full and more complete about what the customer really needs so that the company will create solutions in the form of products to help customers in meet his needs. In the hope that it will make customers satisfied and be loyal to the company. On the one hand, customers through these relationships, will benefit satisfaction that all of their needs will be met by the company (Zeithaml et al., 2006). Estuary of this relationship is a mutually beneficial relationship between customers and companies. Some approaches can be used to provide benefits for a relationship or relational benefit, but the most common are confidence benefits, social benefits, and special impact benefits Social-oriented marketing can also be said to be a marketing process with a view on the social aspects. As explained above, the purpose of social insight is that marketers and individuals or groups are able to complement each other, in other words the marketer creates an offer to the community to meet the desired needs and then the public gets satisfaction with something offered by the marketer.

\section{LITERATURE REVIEW}

\section{Marketing Strategy}

Marketing as it is known, is the essence of a business. Without marketing there is no such thing as a company, but what is meant with the marketing itself people still feel confused. Understanding Kotler's marketing (1997: 8) is a social and managerial process within it individuals and groups get what they need and want by creating, offering and exchanging products with others. Many consider this field identical to or similar to the sales field. Truly, marketing has a broader meaning than sales. The sales field is part of the marketing field, as well as the most important part of the marketing field itself. Marketing means work with the market to realize potential exchanges with the intention of satisfying human needs and wants. If the company is paying more attention many to keep abreast of changing needs and new desires, they will have no trouble recognizing their opportunities. Because consumers are always looking for the best for their lives and of course at an affordable price and with good quality too, that's what triggers the increasingly keen competition that causes the sellers feel the more difficult it is to sell its products in the market.

On the contrary, the buyers feel much benefited because they are free to choose from any party with good quality and product quality this is what drives business experts to find the best way out. The phenomenon of the past is studied and compared with what is symptomatic at present, business tips in producing goods, pricing, promoting and distributing well-analyzed to fit market guidance. A very simple marketing theory always emphasizes that in marketing activities it should be clear who sells what, where, how, when, in what quantity and to whom. The existence of the right strategy will greatly support the marketing activities as a whole. The definition of Harper W (2000: 4) that Marketing is a social process involving important activities that allow individuals and companies to get what they need and want through exchange with other parties and to develop exchange relationships. This definition explains that marketing is a process of business activities to implement a strategic plan that leads to the fulfillment of consumer needs through exchange with other parties.

Basu Swastha (2002: 17) The concept of marketing is a business philosophy that states that satisfying the needs of consumers is a condition economic and social development for the company. The marketing concept is based on outward-looking views. This concept begins by defining a market that clearly focuses on customer needs, integrating all system activities that will affect customers and generate profits through customer satisfaction. 
Kotler and Keller (2009: 58), basically marketing activities include the concept of production, product concept, concept of marketing concept sales and concepts holistic marketing.

\section{The concept of production}

This concept is oriented towards the production process or operation. Manufacturers believe consumers will only buy cheap and easy products obtained. Managers assume that consumers are primarily interested in product availability and low prices. This orientation is useful when companies want to expand the market.

\section{Product concept}

In this concept, marketers assume that consumers prefer products that have superior quality, performance, features or appearance. Organizational managers focus on producing superior products and improving quality over time.

\section{The concept of sales}

This concept is sales-oriented, where marketers assume that consumers must be influenced in order to increase sales. Concept this assumes that consumers generally show reluctance or resistance to buy so it must be persuaded to buy.

The concept of customer-oriented marketing with the assumption that consumers will only be willing to buy products that can meet the needs and desires and provide satisfaction. Marketing concept consists of four pillars namely: target market, customer needs, integrated marketing or integrated and able to generate profits.

The concept of holistic marketing is an approach to a marketing that tries to recognize and reconcile the scope and complexity of marketing activities. Holistic marketing recognizes that everything something can happen to marketing and marketing a broad and perspective integrated often required four components of holistic marketing, namely:

a. Relationship Marketing, has the goal of building a long relationship long satisfactory with the parties that have the main interests (customers, suppliers and distributors) in order gain and maintain business preference and long-term sustainability.

b. Internal Marketing, the internal marketing task is to recruit, train and motivate employees who are able to serve customers with good. Internal marketing takes place on two levels, the first serves as a sales force marketing, advertising, customer service product management, and marketing research. The second marketing takes place by other departments, the department requires thought marketing that customers think, which can penetrate the whole company.

c. Social Responsibility Marketing, a community marketing concept that is demanding marketers to incorporate social and ethical considerations into their marketing practices. Marketers must balance and set the criteria that often conflict with corporate earnings, satisfaction of consumer desires and the public interest.

d. Integrated Marketing, more planning marketing activities and assemble a fully integrated marketing program to create, communicating and delivering value to consumers. In other words, the design and application of a marketing activity is by doing business thoroughly in management demand, resource management and network management.

\section{Social Marketing Concept}

The concept of social-oriented marketing states that the task of the organization is to determine the needs, wants, and interests of the target market and to provide the desired satisfaction more effectively and efficiently than competitors by maintaining and improving the welfare of consumers and society. The concept of social insight invites marketers to build social and ethical considerations in their marketing practices. They must balance and align the 
three factors that often become disputes namely corporate profits, consumer satisfaction, public interest (Philip Kotler, 1997).

Social-minded marketing is a process for influencing human behavior on a large scale, using marketing principles for the sake of community satisfaction not for the benefit of business (Goldman, 2001). Companies must have a sense of moral responsibility, to serve the community as well as possible. This social responsibility in the broad sense, must produce products that can meet the satisfaction of consumers and companies that can improve people's welfare. All this must be in order to create an atmosphere of life that, good and serene with full sense of responsibility is not concerned with corporate profits alone.

According to Zheithaml et al., (2006) relational benefit is what customers will experience when they receive services from companies that have a higher value than what they expect / get from other companies. When a company is able to consistently deliver value from the customer's point of view, then one benefit will be perceived by customers more clearly that will encourage them to maintain relationships. Relational benefits consist of confidence benefits, social benefits, and special treatment benefits (Maria Eugenia et al., 2009).

Customers who feel the value or benefits (relational benefits) of the relationship marketing program, will feel a satisfaction. Kotler $(2006,61)$ argues that customer satisfaction is the level of one's feelings after comparing the perceived performance with hope. Customers experience varying degrees of satisfaction and dissatisfaction, having experienced or perceived each service in accordance with so far where their expectations are met or exceeded (Ndubisi \& Chan, 2005; Kim, 2005). Furthermore, the satisfaction of the consumer will have an effect on his loyalty. According Hurriyati (2005) loyalty refers to the form of behavior of the decisionmaking units to make a continuous purchase of the product of a selected company. According to Leverin and Liljander (2006); customer loyalty is demonstrated by the behavior of making the company the first choice, always using the company's products, always telling positive things about the company's products, and will not turn to competitors.

\section{RESEARCH METHODOLOGY}

This research uses qualitative approach. The definition of qualitative research is an approach that process data derived from the field and then presented in the form of description in accordance with the actual situation. In this qualitative approach the authors use case study strategies, considering that this study provides a very small chance for researchers to control the symptoms or social events under study, in spite of the research being conducted on contemporary events or phenomena in real life (Yin 1996).

There are several methods of approach taken to support the output targets of community service activities, namely as follows:

1. The activity was a survey and preliminary visit to UD.Dua Putra as an industry for various processed snacks from the north coast sea products in Tuban city and PKK Ibu Ds. Kenanti, Kec. Tambakboyo Tuban, East Java.

2. Improved quality, energy efficiency, and processing time for various processed processed seafood from the north coast through vacuum frying design to replace conventional methods, by training, practicing and mentoring to UD.Dua Putra and PKK Ds. Kenanti, Kec. Tambakboyo Tuban, East Java.

3. Increasing the ability of human resources who have the expertise and processing skills of various processed seafood from the north coast to the PKK mothers in the village of 
Catakgayam Selatan, Mojowarno-Jombang. The activity was training, practice, and assistance to PKK Ds. Kenanti, Kec. Tambakboyo Tuban, East Java.

4. Enhancing the design and updating capabilities of product information through the website to expand the marketing of various processed North Coast seafood products to UD. Dua Putra activities are training, practice, and assistance to UD. Two sons and mother PKK Ds. Kenanti, Kec. Tambakboyo Tuban, East Java.

\section{Data Analysis Technique}

This research is descriptive research, with more descriptive of interview result and documentation study. The data have been obtained will be analyzed qualitatively and described in the form of descriptive. According to Patton (Moleong, 2001: 103), data analysis is "the process of arranging the order of data, organizing it into a pattern, category and basic description". The definition provides an overview of how important the position of data analysis is viewed in terms of research objectives. The main principle of qualitative research is to find the theory of data. Data analysis techniques used in this study is to use the steps as proposed by Burhan Bungin (2003: 70), as follows:

\section{a. Data Collection}

Data collection is an integral part of data analysis activities. The data collection activity in this research is by using interview and documentation study.

\section{b. Data Reduction}

Data reduction, defined as the selection process, concentrates attention on simplification and transformation of coarse data arising from written records of records in the field. Reduction is done since data collection begins by making a summary, and editing irrelevant information.

c. Display Data

The data display is a batch description arranged information that provides the possibility of conclusion and action taking. The presentation of qualitative data is presented in the form of narrative text. The presentation can also be in the form of matrices, diagrams, tables and charts.

d. Verification and Confirmation Conclusion

This is the final activity of data analysis. The conclusion of the conclusion of the activities of interpretation, namely finding the meaning of data that has been presented between the display data and conclusion there is activity data analysis that exists. In this sense the analysis of qualitative data is an ongoing, repetitive and ongoing effort. Data reduction issues, data presentation and conclusions or verification are success stories in sequence as a series of related analytical activities.

\section{RESULT AND DISCUSSION}

For the results achieved in the implementation of this service, the range has been $85 \%$ because partners have high morale even though the use of technology is still considered new where those who have been using it manually have used appropriate technology where the manual is now semi-automatic. For production that used to take 8 hours / day for packaging, now it's only 1 hour 30 minutes.

Progress in production makes production higher and can meet buyer demand without leaving quality standards. Viewed from the economic side, packaging for various seafood products produces increased quality and quantity, more efficient and effective and the benefits of the higher welfare of the community as well. Soekartawi (1989) Efficient is a benchmark for an effort to achieve maximum benefit for certain levels of input use. With the availability of efficiency and effectiveness can be realized by partners with the help of foot sealers, the demand can be met with standard packaging quality, the product is not easy to cool. So that it 
has competitiveness signifies an adequate level of production growth (Kaaro and Hartono, 2002). Even the counseling and mentoring of the service team, diversified marketing activities and the spirit of entrepreneurial spirit are increasingly motivated partners

With the implementation of this service, it can be concluded that:

1. Bhayangkara University Surabaya can carry out its function, namely Community Service which is an activity in contributing ideas for general national development.

2. As for partners having their address at Ds. Kenanti Kec. Tambakboyo-Tuban East Java is assisted in solving the problem of increasing packaging with sealer foot equipment which in the first case in the case of one-time packaging takes 8 hours now with the use of 30 minutes of production technology to be efficiently realized in production. And for Mitra II the PKK mother in Rt2-Rw11 Ds. Kenanti, Kec. Tambakboyo Tuban, East Java, they got an understanding of the use of technology in the process of activities making effective production activities.

3. The higher spirit and entrepreneurial spirit is proven by its ability to produce other products derived from marine waste as potential in Tuban. Fish skin crackers can be produced from processed products of business activities in DUTRA "DUA PUTRA". The resulting crackers are an innovative result that starts from the waste of fish skin processed into a unique processed product and has a high selling value.

4. Management of human resources occurs increasing awareness of togetherness to work together and the spirit of business / entrepreneurship is higher because there is support from groups of universities that are considered to have experience, insight and ability to make support for partners.

\section{References}

Baker, W.E, dan J.M. Sinkula, 2002, Market Orientation, Learning Orientation and Product Innovation: Delving Into the Organization's Black Box, Journal of Market Focused Management. Vol. 5. No. 5, pp. 5-23.

Boer, H., \& Duringa, W. E, 2004, Innovation, what innovation? A comparison between product, process, and organizational innovation, International Journal of Technology Management, Vol.22. p. 83-107.

Bradley, F., dan O'Reagain, S, 2001, Deriving international competitive advantage in SMEs through productmarket and business system resource llocation. Irish Journal of Management, 22 (2), 19-44.

Brockmand B, Morgan F, 2003, The role of existing knowledge in new product innovativeness and performance. Decis Sci. J., 32(2): 385-419.

Bruggeman, W. dan Koster, 2000, Market orientation, Australian Journal of Management Strategy: 73: 507-510.

Bueno, E. dan P. Ordoñez, 2004, Innovation and learning in the knowledge-based economy: Challenges for the firm. Inter. J. Technol. Manage., 276(7): 531 533.

Maghfiroh, I. 2000. Effect of adding binder to the characteristics of nugget from catfish (Pangasius hypothalamus). Essay. Fisheries Product Technology Study Program. Faculty of Fisheries, Bogor Agricultural University. Bogor.

Moyle, P. and J.J. Cech. 1988. Fishes an Introduction to Ichtyology. Second Edition. Department of Wildlife and Fisheries Biology. University of California. 559 p.

Nikolsky, G. V. 1963. The Ecology of Fishes. Academic Press. London

Nurfajrie, Suminto, S. Rejeki. 2014. Utilization of Macroalgae for the Growth of Abalone (Holiotis squamata) in Cultivation of Enlargement. Journal of Vol. 3 No. 4.

Hennig-Thurau, T., Gwinner, K. P., \& Gremler, D. D. (2002). Understanding relationship marketing outcomes: An integration of relational benefits and relationship quality. Journal of Service Re-search, 4(3), 230-247.

Kau, A. K., \& Elizabeth, W. Y. L. (2006). The effect of service recovery on satisfaction: A compari-son between complaints and non-complaints. Journal of Service Marketing, 20(2), 101-111.

Kim, H. D. (2005). The relationships between service quality, customer satisfaction, and repurchase intention in Korean private golf courses.Retriev-ed on Des,27,2015from http://gradworks.umi.com/31/77/3177086.html. 
Kinard, B. R., \& Capella, M. L. (2006). Relationship marketing: The influence of consumer involve-ment on perceived service benefits. Journal of Services Marketing, 20(6), 359-368.

Kotler, Philip. 2001. Manajemen Pemasaran di Indonesia : Analisis, Perencanaan, Implementasi dan Pengendalian. Salemba Empat. Jakarta.

Nova Retnowati is an assistance professor at Bhayangkara University. She majorly in Management department.

Dr. Muslichah Erma Widiana is an associate professor at the Bhayangkara University. Her current research interests include marketing, human resource and management.

Soeharjoepri is an associate professor at natural science in Sepuluh November Institute of Technology. 